\title{
Chemicals with a natural reference for controlling water hyacinth, Eichhornia crassipes (Mart.) Solms
}

\author{
Tarek Abd El-Ghafar El-Shahawy* \\ Botany Department, National Research Centre, El-Tahrir Street, Dokki, Cairo, 12622, Egypt
}

Received: April 9, 2015

Accepted: June 20, 2015

\begin{abstract}
Life cannot exist without water. Appropriate management of water, from the water's source to its utilization, is necessary to sustain life. Aquatic weeds pose a serious threat to aquatic environments and related eco-environments. Short- and long-term planning to control aquatic weeds is extremely important. Water hyacinth, Eichhornia crassipes (Mart.) Solms, is one of the world's worst pests with a bad reputation as an invasive weed. In this study we are seeking the possibility of using certain chemicals with a natural background, for controlling water hyacinth since there is a delicate balance that needs to be taken into account when using herbicides in water. Five compounds, namely: acetic acid, citric acid, formic acid, and propionic acid, in three concentrations (10, 15, and $20 \%$ ) were applied (i.e. as a foliar application under wire-house conditions) and compared with the use of the herbicide glyphosate $\left(1.8 \mathrm{~kg} \cdot \mathrm{ha}^{-1}\right)$. All of the five compounds performed well in the control of the water hyacinth. As expected, the efficacy increased as the concentration was increased from 10 to $20 \%$. With formic and propionic acids, the plants died earlier than when the other acids or the herbicide glyphosate, were used. Acetic acid came after formic and propionic acids in terms of efficacy. Citric acid ranked last. Formic acid/propionic acid mixtures showed superior activity in suppressing water hyacinth growth especially at the rate of $(8: 2)$ at the different examined concentrations ( 3 or 5 or $10 \%$ ) compared to the formic acid/acetic acid mixtures. Using the formic acid/propionic acid mixture $(8: 2 ;$ at $3 \%)$ in the open field, provided good control and confirmed the viability of these chemicals in the effective control of water hyacinth. Eventually, these chemical treatments could be used on water for controlling water hyacinth. In the future, these chemicals could probably replace the traditional herbicides widely used in this regard. These chemicals are perceived as environmentally benign for their rapid degradation to carbon dioxide and water. For maximum efficiency thorough coverage especially in bright sunlight is essential.
\end{abstract}

Key words: aquatic weeds, herbicides, natural reference/background, water hyacinth, invasive weeds, water issue

\section{Introduction}

Water issue has become the focus of attention in the world today. Not surprisingly, a conflict over water and its sources is inevitably coming. The higher the aspirations of the countries in growth and prosperity the greater the need for water as a key element. Many countries are in a difficult position regarding water in their future. Searching for the alternatives and maintaining current resources has become a necessity. The Nile River is the primary source of water for Egypt and is considered as the lifeblood for all Egyptians. Today, more than ever, Egypt urgently needs to develop new programs for managing water.

Aquatic weeds are a great problem in many countries. No one can deny the problems associated with aquatic weeds. The aquatic weeds have an impact on the economic and social life of communities. Their effects on human health and the environment are particularly complex and difficult to manage (Charudattan 2001; Jayan and Sathyanathan 2012). There are major differences between the problems caused by aquatic weeds and those caused by terrestrial plants in the different agro-ecosystems.
Aquatic plants cause water to be lost and work against the smooth flow of water, navigation, and the good management of water. Many impacts were recorded on increasing water table, affecting concrete facilities like bridges, harbour many of the harmful pests and interfere with hydroelectric systems. The recreational uses of aquatic resources are also disrupted. An important statement of the Egyptian Government, Ministry of Irrigation and Water Resources confirmed that evapotranspiration caused by aquatic weeds leads to a $40 \%$ loss of Egypt's share of water annually (Goldsmith and Hildyard 1984). Kassas (1980) confirmed that water losses are 2, 3, or even 6 times higher in grass-covered reservoirs than they are in open waters.

Controlling aquatic weeds has a special position for the sensitivity of the place in which they grow. Charudat$\tan (2001)$ acknowledged that the challenge is to control these weeds (1) in a cost-effective manner that society can afford, (2) with the most effective and safe methods available, (3) with minimal adverse side-effects, (4) with public acceptance of the control practices, and (5) in a sustainable manner that reduces recurrent costs and pro- 
motes environmental balance. Control practices include manual, mechanical, physical, chemical, and biological methods (Lancar and Krake 2002). Mechanical methods are being practiced widely for the multiple advantages that they offer, including: utilization of available manpower resources, being eco-friendly, being target-specific, and providing speedy results. Mechanical application methods, however, need constant attention as re-growth can occur quickly (i.e., from submerged rootstocks) and can be widespread (Wells and Clayton 2005). Mechani$\mathrm{cal} / \mathrm{manual}$ methods may be rather expensive (Chisholm 2006). Biological control is a promising approach and considered one of the safest, economically sustainable, and long-term options in managing aquatic weeds. A good return is achieved when used in integration with other control techniques where biological agents can stress their host plants, making them more susceptible to other controlling forces. Biological control, however, involves some risk especially when introducing a nonnative organism to a new area. Herbicides provide effective and quick control of aquatic weeds. Herbicides are cheap and easy to use when compared with mechanical or biological methods. Chemical control with the use of herbicides is very restricted, though, because of the potential risks that may be associated with their use. Regardless of any controversy, herbicides are still the most popular and reliable technique for controlling aquatic weeds worldwide despite the fact that they have the disadvantage of polluting water and the surrounding media. In many countries, including Egypt, the use of herbicides is facing very harsh legislation because of the potential risks involved.

Because of the problems associated with herbicides and the objections to using them on water, there is a new developing interest regarding natural product-based herbicides. Natural products with potential herbicidal activity have had a long history of experimentation on terrestrial weeds, but little has been mentioned of their effects on aquatic weeds (Bhadoria 2001; Duke et al. 2002; Jabran et al. 2010; El-Shahawy and Abdelhamid 2013; Nekonam et al. 2014). The US Patent Office has lately approved many patents with natural ingredients such as lemongrass oil, propionic acid, acetic acid, formic acid, fatty acids, essential oils, and monoterpenes, that can be used effectively in controlling weeds (Chase et al. 2004; Bickers et al. 2005; Wilson et al. 2007; Campbell et al. 2009; Fernandez et al. 2009; Koivunen and Marrone 2013). The compositions containing organic acids act by influencing the cell membrane of the plants, causing a rapid breakdown/desiccation of foliage tissue upon contact (Smith-Fiola and Gill 2014).

The water hyacinth, Eichhornia crassipes (Mart.) Solms, is one of the world's 100 worst invaders according to the IUCN's list (Lowe et al. 2000), and an updated version by Luque et al. (2013). It is a very fast-growing plant (AboulEnein et al. 2011), with populations that can double their mass (under favorable conditions) every 7-10 days (Gorham 2008). Eichhornia crassipes reproduces vegetatively and sexually. The former is more important for the plant's rapid expansion and colonization through the formation of stolons. Growth rate has been calculated in some countries to be an increase in biomass of 400-700 $t$ per ha per day (Téllez et al. 2008). Losing a huge quantity of water, impeding water-flow, and affecting the abundance of freshwater species including fish and submerged aquatic plants, are of the negative impacts of E. crassipes. Dense vegetation mats of $E$. crassipes affect water availability and obstruct aquatic navigation (Labrada 2003). Environmentalists confirm that water hyacinth infestations in Africa have resulted in population migrations because people are unable to continue fishing (Babatunde and Oladimeji 2014). Water hyacinth infestations in Africa have also resulted in an increase in various diseases such as malaria, as well as a reduced use of waterways for transport and recreation (Findlay and Jones 1996). The water hyacinth costs Egypt approximately 5 billion cubic meters of water-loss annually. That amount would be enough water to cultivate more than half a million acres of farmland or to supply a city like Cairo (the capital) which has a population of near 20 million people (Kassas 1980). Three basic techniques exist for the control of the water hyacinth: chemical, mechanical, and biological (Parolin et al. 2012). Mechanical and manual removals are almost the only ways approved to control the water hyacinth in Egypt, even though they are largely ineffective. Throughout the world, great effort has been put into the control of the water hyacinth, with varying degrees of success (Ray et al. 2009; Stubbs and Kennedy 2012).

In this study, we present a proposal for using acetic acid, citric acid, formic acid, and propionic acid as safe chemicals for controlling the water hyacinth; the most dangerous threat to aquatic ecosystems in Egypt.

\section{Materials and Methods}

An experiment was conducted under wire-house conditions to study the potential effect of certain chemicals (e.g., acetic acid, citric acid, formic acid, and propionic acid) at different concentrations $(10,15,20 \%)$ for controlling water hyacinth using the herbicide glyphosate at a rate of $1.8 \mathrm{~kg} \cdot \mathrm{ha}^{-1}$ (Roundup containing $36 \%$ glyphosate in form of $480 \mathrm{~g} \cdot \mathrm{l}^{-1}$ isopropylamine salt, Monsanto Co.) and water as the controls. Acetic acid (99\%), citric acid (anhydrous, PB 93, 99.5\%), and formic acid (85\%) were purchased from El Nasr Pharmaceutical Chemicals Co., AboZaabal, Egypt. Propionic acid (> 99.5\%) was purchased from Sigma-Aldrich, Germany.

The plants were collected from clean, renewable freshwater of the Nile River at El-Behara Governorate, Damanhour, Egypt. The plants were prepared by removing the dead parts, suspended solids, and suspended organic matters. After carefully washing several times with tap water, the plants were put separately into plastic pots (30 cm height $\times 28 \mathrm{~cm}$ diameter; 4 plants $\cdot$ pot $^{-1}$ ), each containing $18 \mathrm{l}$ of freshwater and $20 \mathrm{~g}$ of Abo Qir Vermex fertilizer; a product of Abo Qir Fertilizers Company, Egypt, containing $22 \% \mathrm{~N}, 5 \% \mathrm{P}$, and $0 \% \mathrm{~K}$. The treatments were replicated three times in a randomized complete design.

The plants were sprayed thoroughly (during the evening) with $200 \mathrm{ml}$ of the different concentrations per treatment. The plants were monitored for 10 days. At the end of the 10 days, the fresh and dry weights $\left(g \cdot\right.$ plant $\left.^{-1}\right)$ were estimated. The dry weight was determined after drying at $70^{\circ} \mathrm{C}$ for $48 \mathrm{~h}$. 
Formic acid was examined in combination with acetic or propionic acid at ratios of $8: 2,6: 4$, and $2: 8$ as they were the most effective in suppressing water hyacinth growth. Three concentrations less than those previously examined $(3,5,10 \%)$ were applied following the same procedure on the same number of the plants. The data on vegetative growth (fresh and dry weights) were also taken after 10 days.

To examine two different conditions of brightness and the absence of sunlight, the formic acid/propionic acid mixture $(8: 2 ;$ at $3 \%)$ was applied at noon and late in the afternoon under the same circumstances as those used when preparing the experiment and taking data.

A formic acid/propionic acid mixture (8:2; at $3 \%$ ) was applied in the open field to be evaluated under natural conditions. Four replicates were used on an area $2 \times 2 \mathrm{~m} /$ each. From each plot, one randomized point, measuring $70 \times 70 \mathrm{~cm}$ was used to record the estimated fresh and dry weights $(\mathrm{g})$.

All the data were statistically analyzed using ANOVA and the LSD test at $5 \%$ probability, to compare the means.

\section{Results}

The various compounds showed a high activity for suppressing water hyacinth growth when applied at the different examined concentrations (Table 1). As expected the efficacy increased, as the concentration was increased from 10 to $20 \%$. The high concentration $(20 \%)$ was most effective compared to the low and medium concentrations ( $10 \%$ and $15 \%$, respectively). The formic, and propionic acids gave the best control of water hyacinth, causing symptoms within $24 \mathrm{~h}$, even when compared with glyphosate. Acetic acid controlled water hyacinth by $83-94 \%$. Citric acid achieved a $41-65 \%$ reduction in comparison with the water spray. Propionic acid worked well, especially at the medium and high concentrations (15 and 20\%, respectively); providing up to $100 \%$ control. Formic acid had a unique effect. An estimated 100\% failure was recorded at all examined concentrations of this treatment (Table 1). Overall, the efficiency of the individually used formic acid, propionic acid, citric acid, and acetic acid surpassed glyphosate, which did provide up to a $90 \%$ growth reduction over the water spray. Wilting progressing to yellowing and then browning occurred within 7-10 days of exposure to glyphosate, which is considered late compared to the results obtained by the different organic acids.

Use of formic acid in a mixture with propionic acid or acetic acid had a good impact in increasing water hyacinth control. All the combinations, irrespective of their concentrations, showed good activity (Table 2). Overall, the formic acid/propionic acid mixtures were, to a certain extent, most effective. A distinct effect was noticed in this regard for the $8: 2$ mixture. Applying the formic acid/ propionic acid mixture $(8: 2)$ at a concentration of $10 \%$ caused the water hyacinth plants to die within 5 days. On the other hand, the $3 \%$ and $5 \%$ concentrations contributed to a decrease in biomass varying from 84 to $97 \%$ in comparison with the water spray. Formic acid/acetic acid mixtures also had a good impact especially at the high concentration (10\%) of the $6: 4$ and $2: 8$ mixtures, and death occurred in 10 days. At the concentrations of $3 \%$ and $5 \%$, formic acid/acetic acid mixtures recorded a 62 $89 \%$ growth suppression. Visual follow-up that was made several hours after treatment showed rapid phytotoxicity to water hyacinth. The leaves turned light brown and there was a shrinking of the plant biomass particularly with the highly effective combination of treatments. The plants eventually died because of dehydration. Symptoms of phytotoxicity appeared in as short a time as $2 \mathrm{~h}$.

Table 1. Effect of acetic, citric, formic, and propionic acids sprayed at different concentrations, in comparison with the herbicide glyphosate, on the growth of water hyacinth under wire-house conditions

\begin{tabular}{|c|c|c|c|c|c|}
\hline \multirow[b]{2}{*}{ Treatment } & \multirow{2}{*}{$\begin{array}{c}\text { Concentration } \\
{[\%]}\end{array}$} & \multicolumn{4}{|c|}{ Water hyacinth growth } \\
\hline & & $\begin{array}{c}\text { Fr. Wt. } \\
{\left[\mathrm{g} \cdot \text { plant }^{-1}\right]}\end{array}$ & inhibition [\%] & $\begin{array}{c}\text { Dr. Wt. } \\
{\left[\mathrm{g} \cdot \text { plant }^{-1}\right]}\end{array}$ & inhibition [\%] \\
\hline \multirow[t]{3}{*}{ Acetic acid } & 10 & 8.4 & 85 & 1.1 & 83 \\
\hline & 15 & 8.1 & 86 & 1.1 & 83 \\
\hline & 20 & 3.4 & 94 & 0.5 & 92 \\
\hline \multirow[t]{3}{*}{ Citric acid } & 10 & 28.9 & 48 & 3.9 & 41 \\
\hline & 15 & 21.4 & 62 & 3.0 & 54 \\
\hline & 20 & 19.6 & 65 & 3.3 & 50 \\
\hline \multirow[t]{3}{*}{ Formic acid } & 10 & 0.0 & 100 & 0.0 & 100 \\
\hline & 15 & 0.0 & 100 & 0.0 & 100 \\
\hline & 20 & 0.0 & 100 & 0.0 & 100 \\
\hline \multirow[t]{3}{*}{ Propionic acid } & 10 & 9.3 & 83 & 1.3 & 80 \\
\hline & 15 & 0.0 & 100 & 0.0 & 100 \\
\hline & 20 & 0.0 & 100 & 0.0 & 100 \\
\hline $\begin{array}{l}\text { Glyphosate } \\
\text { (Roundup 36\%) }\end{array}$ & $1.8 \mathrm{~kg} \cdot \mathrm{ha}^{-1}$ & 5.5 & 90 & 1.4 & 78 \\
\hline Water & & 56.0 & - & 6.6 & - \\
\hline $\mathrm{LSD}_{0.05}$ & & 4.4 & 7.9 & 0.7 & 12.6 \\
\hline
\end{tabular}

Fr. Wt. - Fresh Weight; Dr. Wt. - Dry Weight 
Table 2. Effect of formic acid/propionic acid mixtures and formic acid/acetic acid mixtures sprayed at different concentrations, on the growth of the water hyacinth under wire-house conditions

\begin{tabular}{|c|c|c|c|c|c|c|}
\hline \multirow[b]{2}{*}{ Treatment } & \multirow[b]{2}{*}{ Ratio } & \multirow{2}{*}{$\begin{array}{c}\text { Concentration } \\
{[\%]}\end{array}$} & \multicolumn{4}{|c|}{ Water hyacinth growth } \\
\hline & & & $\begin{array}{c}\text { Fr. Wt. }{ }^{*} \\
{\left[\mathrm{~g} \cdot \text { plant }^{-1}\right]}\end{array}$ & inhibition [\%] & $\begin{array}{c}\text { Dr. Wt. } \\
{\left[\mathrm{g} \cdot \text { plant }^{-1}\right]}\end{array}$ & inhibition [\%] \\
\hline \multirow{9}{*}{$\begin{array}{l}\text { Formic acid + propionic } \\
\text { acid }\end{array}$} & \multirow[t]{3}{*}{$8: 2$} & 3 & 6.0 & 90 & 1.0 & 84 \\
\hline & & 5 & 2.0 & 97 & 0.3 & 94 \\
\hline & & 10 & 0.0 & 100 & 0.0 & 100 \\
\hline & \multirow[t]{3}{*}{$6: 4$} & 3 & 14.5 & 76 & 2.4 & 59 \\
\hline & & 5 & 2.0 & 96 & 0.4 & 94 \\
\hline & & 10 & 1.7 & 97 & 0.3 & 95 \\
\hline & \multirow[t]{3}{*}{$2: 8$} & 3 & 16.8 & 71 & 2.6 & 56 \\
\hline & & 5 & 5.4 & 91 & 0.9 & 84 \\
\hline & & 10 & 3.4 & 95 & 0.6 & 91 \\
\hline \multirow[t]{9}{*}{ Formic acid + acetic acid } & \multirow[t]{3}{*}{$8: 2$} & 3 & 8.6 & 86 & 1.3 & 78 \\
\hline & & 5 & 8.2 & 87 & 1.4 & 77 \\
\hline & & 10 & 4.8 & 92 & 0.7 & 87 \\
\hline & \multirow[t]{3}{*}{$6: 4$} & 3 & 11.5 & 80 & 1.9 & 68 \\
\hline & & 5 & 6.7 & 89 & 1.2 & 81 \\
\hline & & 10 & 0.0 & 100 & 0.0 & 100 \\
\hline & \multirow[t]{3}{*}{$2: 8$} & 3 & 13.9 & 77 & 2.2 & 62 \\
\hline & & 5 & 7.8 & 86 & 1.4 & 76 \\
\hline & & 10 & 0.0 & 100 & 0.0 & 100 \\
\hline Water & & & 59.0 & - & 6.0 & - \\
\hline $\mathrm{LSD}_{0.05}$ & & & 5.8 & 9.3 & 1.1 & 16.0 \\
\hline
\end{tabular}

*explanations - see table 1

Table 3. Effect of formic acid/propionic acid mixture $(8: 2$; at $3 \%)$ sprayed under bright sunlight and sprayed when there was a lack of sunlight, on the growth of the water hyacinth under wire-house conditions

\begin{tabular}{|c|c|c|c|c|c|c|c|}
\hline \multirow[b]{2}{*}{ Treatment } & \multirow[b]{2}{*}{ Ratio } & \multirow{2}{*}{$\begin{array}{c}\text { Concen- } \\
\text { tration } \\
{[\%]}\end{array}$} & \multicolumn{5}{|c|}{ Water hyacinth growth } \\
\hline & & & $\begin{array}{l}\text { conditions of } \\
\text { application }\end{array}$ & $\begin{array}{c}\text { Fr. Wt. } \\
{\left[\mathrm{g} \cdot \text { plant }^{-1}\right]}\end{array}$ & inhibition [\%] & $\begin{array}{c}\text { Dr. Wt.* } \\
{\left[\mathrm{g} \cdot \text { plant }^{-1}\right]}\end{array}$ & inhibition [\%] \\
\hline \multirow[t]{2}{*}{$\begin{array}{l}\text { Formic acid }+ \\
\text { propionic acid }\end{array}$} & $8: 2$ & 3 & $\begin{array}{l}\text { in the absence } \\
\text { of sunlight }\end{array}$ & 31.0 & 74 & 3.6 & 71 \\
\hline & & & $\begin{array}{l}\text { in bright } \\
\text { sunlight }\end{array}$ & 12.6 & 89 & 1.6 & 87 \\
\hline Water & & & & 117.0 & - & 12.6 & - \\
\hline $\mathrm{LSD}_{0.05}$ & & & & 14.4 & 5.1 & 1.1 & 9.1 \\
\hline
\end{tabular}

*explanations - see table 1

Table 4. The effect of the formic acid/propionic acid mixture $(8: 2)$ sprayed at a concentration of $3 \%$ (in bright sunlight), on the growth of the water hyacinth under open field conditions

\begin{tabular}{|c|c|c|c|c|c|c|c|}
\hline \multirow[b]{2}{*}{ Treatment } & \multirow[b]{2}{*}{ Ratio } & \multirow{2}{*}{$\begin{array}{c}\text { Concen- } \\
\text { tration } \\
{[\%]}\end{array}$} & \multicolumn{5}{|c|}{ Water hyacinth growth } \\
\hline & & & $\begin{array}{c}\text { conditions of } \\
\text { application }\end{array}$ & $\begin{array}{c}\text { Fr. Wt.* } \\
{\left[\mathrm{g} \cdot 0.5 \mathrm{~m}^{2}\right]}\end{array}$ & inhibition [\%] & $\begin{array}{l}\text { Dr. Wt.* } \\
{\left[\mathrm{g} \cdot 0.5 \mathrm{~m}^{2}\right]}\end{array}$ & inhibition [\%] \\
\hline $\begin{array}{l}\text { Formic acid }+ \\
\text { propionic acid }\end{array}$ & $8: 2$ & 3 & $\begin{array}{l}\text { in bright } \\
\text { sunlight }\end{array}$ & 281.3 & 61 & 35.2 & 52 \\
\hline Water & & & & 718.8 & - & 73.5 & - \\
\hline $\mathrm{LSD}_{0.05}$ & & & & 152.9 & - & 11.3 & - \\
\hline
\end{tabular}

*explanations - see table 1 
The effect of sunlight on increasing the herbicidal efficiency of the formic acid/propionic acid mixture $(8: 2)$ applied at the $3 \%$ concentration was quite obvious. Treatment under bright sunlight resulted in inhibiting water hyacinth by up to $89 \%$, vs. $71 \%$ in the absence of sunlight (Table 3). Symptoms occurred faster in bright sunlight. The effects appeared within $30 \mathrm{~min}$ of application under bright sunlight, while the effects took longer $(2 \mathrm{~h})$ in the absence of sunlight.

Applying the formic acid/propionic acid mixture (8:2; at $3 \%$ ) in the open field provided good activity and did not differ greatly from the results obtained under wire-house conditions (Table 4). The treatment significantly suppressed fresh weight by $61 \%$ and dry weight by $52 \%$, as compared with the water spray. The response appeared late compared to the results obtained under wire-house conditions. Symptoms of phytotoxicity appeared within 3-5 h.

\section{Discussion}

Acetic acid (the mother component in vinegar), citric acid (the acid of citrus fruits), formic acid (the active ingredient in ant venom), and porpionic acid (a naturally occurring carboxylic acid with physical proprieties in-between those of the smaller carboxylic acids, formic, and acetic acids and the larger fatty acids) have been well documented as safe, effective, and cheap herbicides for controlling terrestrial weeds (Frederickson et al. 2005; Abouziena et al. 2009; Ivany 2010; Smith-Fiola and Gill 2014). However little is mentioned about their influence as aquatic herbicides (Anderson 2007). The water hyacinth is one of the most damaging pest-plants in the world. In our present study, the use of the acids: acetic, citric, formic, porpionic showed good activity in controlling water hyacinth, even if compared with the use of glyphosate. Glyphosate is the world's most heavily used weed killer (Smith-Fiola and Gill 2014). The herbicidal activity was concentrationdependent. The chemicals had a burning effect on the plants. The effects appeared clearly within hours of the treatment, which supports the action of the chemicals as contact herbicides. They caused foliage to brown within $3-5 \mathrm{~h}$, followed by death as an eventual result. Our interpretations are consistent with those of researchers who suggested that the mechanism of action of such chemicals is similar to that of paraquat and diquat herbicides since the chemicals cause rapid dissolution of cell membrane integrity resulting in desiccation of foliar tissues, and ultimately plant death (Murphy 1999; Owen 2002; Anonymous 2013).

Using a formic acid/propionic acid mixture or a formic acid/acetic acid mixture at different concentrations acted more effectively. Our target when using these mixtures was to improve the efficiency by reducing the applied doses since such a reduction would minimize pollution and reduce costs. This result was largely achieved. Formic acid/propionic acid mixtures seemed to work well compared to formic acid/acetic acid mixtures, especially at the ratio of $8: 2$ and at a concentration of $10 \%$. Even though a great influence was noted at the high concentration $(10 \%)$ of the formic acid/acetic acid mixtures, the formic acid/propionic acid mixtures remained the best in terms of efficiency and speed of activity at all the examined concentrations. Using these chemicals in mixtures as a tool for increasing potential herbicidal activity has been discussed by several researchers (Wilson et al. 2007; Fernandez et al. 2009; Koivunen and Marrone 2013).

It is pretty obvious that bright sunlight, unlike a lower amount of sunlight, had a good impact in increasing the efficiency of formic acid/propionic acid mixture (8:2) applied at a concentration of $3 \%$. Formic and propionic acids are classified as weak acids. These acids primarily function as contact herbicides. Most contact herbicides rely on light reactions inside the plant cells to cause an effect (Summers 1980; Bus and Gibson 1984; Lance and Gibson 2004). Application made when there is less sunlight, often limits the activity of contact herbicides. Interfering with one or more of the main biological processes inside the plant is not necessarily the main mode of action of formic acid or propionic acid or any other compound examined in this study. The corrosive or burning effect on living tissues including green vegetation is ascribed mainly to their acidic nature, and strong dehydrating properties. Chemically, these compounds are capable of destroying cell membrane integrity via amide hydrolysis and ester hydrolysis (Wikipedia 2014). The initiation of endogenous reactions following destruction is possible since cell integrity was lost. On cell membrane disruption, a general mixing of cell contents results in fairly widespread enzymic and nonenzymic chemical reactions (Romero-Sierra and Webb 1981).

Some variations were observed between the results obtained under field conditions and those obtained under wire-house conditions concerning the application of the formic acid/propionic acid mixture at the ratio of $(8: 2)$ and at a concentration of $3 \%$. Application under wire-house conditions was most effective. There are many biotic and abiotic factors that could interfere with the action of these chemicals under field conditions and this may explain the decline in activity and the delay in response compared to the results obtained under wire-house conditions.

In conclusion such chemicals could be promising for controlling water hyacinth. These chemicals rapidly degrade in the environment to carbon dioxide and water. In terms of safety, they are perceived as environmentallyfriendly products. For maximum results good spray coverage (to runoff) especially in bright sunlight, is necessary.

\section{References}

Aboul-Enein A.M., Al-Abd A.M., Shalaby E.A., Abul-Ela F., Nasr-Allah A.A., Mahmoud A.M., El-Shemy H.A. 2011. Eichhornia crassipes (Mart.) Solms. Plant Signaling and Behaviour 6 (6): 834-836.

Abouziena H.F.H., Omar A.A.M., Sharma S.D., Singh M. 2009. Efficacy comparison of some new natural-product herbicides for weed control at two growth stages. Weed Technology 23 (3): 431-437.

Anderson L.W.J. 2007. Potential for sediment-applied acetic acid for control of invasive Spartina alterniflora. Journal of Aquatic Plant Management 45: 100-105. 
Anonymous 2013. Paraquat fact sheet. Paraquat Information Center on behalf of Syngenta Crop Protection AG. Available on: http://paraquat.com/knowledge-bank/paraquatfact-sheet [Accessed: April 15, 2013]

Babatunde M.M., Oladimeji A.A. 2014. Comparative study of acute toxicity of paraquat and galex to Oreochromis niloticus. International Journal of Advanced Scientific and Technical Research 4 (3): 437-444.

Bhadoria P.B.S. 2011. Allelopathy: a natural way towards weed management. American Journal of Experimental Agriculture 1 (1): 7-20.

Bickers U.M., Bradsley R.A., Briggs G.G., Green S.A., Pate A.E., Sanwald E.F., Stock D. 2005. Use of citric acid derivatives as adjuvants for herbicides (EP 1586238 A2). Available on: http://www.google.com.mx/patents/EP1586238A2?cl=en [Accessed: October 19, 2005]

Bus J.S., Gibson J.E. 1984. Paraquat: model for oxidant-initiated toxicity. Environmental Health Perspectives 55: 37-46.

Campbell B., Fernandez L., Koivunen M., Marrone P.G. 2009. Propionic acid as an herbicide (WO 2009055632 A2). Available on: http://www.google.com/patents/ WO2009055632A2?cl=en [Accessed: April 30, 2009]

Charudattan R. 2001. Are we on top of aquatic weeds? Weed problems, control options, and challenges. p. 43-68. In: "The World's Worst Weeds" (Riches C.R., ed.). Proceedings of an International Symposium. Brighton, UK, 12 November 2001, 118 pp.

Chase C.A., Scholberg J.M., MacDonald G.E. 2004. Preliminary evaluation of nonsynthetic herbicides for weed management in organic orange production. Proceedings of the Floride State Horticultural Society 117: 135-138.

Chisholm W.P. 2006. Review of aquatic weed control methods in New Zealand. p. 787-790. In: Proceedings of the 15th Australian Weeds Conference (C. Preston, J.H. Watts, N.D. Crossman, eds.). Weed Management Society of South Australia, Adelaide, Australia, 24-28 September 2006, 904 pp.

Duke S.O., Dayan F.E., Rimando A.M., Schrader K.K., Aliotta G., Oliva A., Romagni J.G. 2002. Chemicals from nature for weed management. Weed Science 50 (2): 138-151.

El-Shahawy T.A., Abdelhamid, M.T. 2013. Potential allelopathic effect of six Phaseolus vulgaris recombinant inbred lines for weed control. Australian Journal of Basic and Applied Sciences 7 (1): 462-467.

Fernandez L., Campbell B., Huang H., Koivunen M., Marrone P.G. 2009. Natural herbicide containing lemongrass essential oil (US 20090099022 A1). Available on: http:// www. google.com/patents/US20090099022 [Accessed: April 16, 2009]

Findlay J.B.R., Jones D. 1996. The integrated control of water hyacinth, Eichhornia crassipes, in Africa based on Roundup ${ }^{\circledR}$ herbicide treatments. p. 435-440. In: "Proceedings of the IX International Symposium on Biological Control of Weeds" (V.C. Moran, J.F. Hoffmann, eds.). University of Cape Town, Stellenbosch, South Africa, 19-26 January 1996, 563 pp.

Frederickson M.E., Greene M.J., Gordon D.M. 2005. Ecology: 'Devil's gardens' bedevilled by ants. Nature 437: 495496.

Goldsmith E., Hildyard N. 1984. Water losses: exceeding gains? Chapter 5. In: The Social and Environmental Effects of Large Dams. Vol. 1. Overview. Wadebridge Ecological
Centre, Worthyvale Manor Camelford, Cornwall PL32 9TT, UK.

Gorham P. 2008. Aquatic weed management in waterways and dams. Primefacts 30: 1-8. Available on: http://www.dpi. nsw.gov.au/data/assets/pdf_file/0020/256403/Aquaticweed-management-in-waterways-and-dams.pdf [Accessed: November 1, 2008]

Ivany J.A. 2010. Acetic acid for weed control in potato (Solanum tuberosum L.). Canadian Journal of Plant Science 90 (4): 537-542.

Jabran K., Farooq M., Hussain M., Hafeez-ur-Rehman, Ali M.A. 2010. Wild oat (Avena fatua L.) and canary grass (Phalaris minor Ritz.) management through allelopathy. Journal of Plant Protection Research 5 (1): 41-44.

Jayan P.R., Sathyanathan N. 2012.Aquatic weed classification, environmental effects and the management technologies for its effective control in Kerala, India. International Journal of Agricultural and Biological Engineering 5 (1): 76-91.

Kassas M. 1980. Environmental aspects of water resources development. p. 1-6. In: "Water Management in Developing Countries" (A.K. Biswas et al., eds.). Pergamon, Oxford, UK, 69 pp.

Koivunen M., Marrone P. 2013. Uses of thaxtomin and thaxtomin compositions as herbicides (US 8476195 B2). Available on: http://www.google.com/patents/US8476195 [Accessed: July 2, 2013]

Labrada R. 2003. The need for weed risk assessment. p. 1-6. In: "FAO Expert Consultation on Weed Risk Assessment" (R. Labrada, ed.), FAO, Room, Italy, 11-13 June 2002, 117 pp.

Lancar L., Krake K. 2002. Aquatic weeds and their management. International Commission on Irrigation and Drainage. 65 pp. Available on: http:/www.icid.org/weed_report.pdf [Accessed: March, 2002]

Lance R., Gibson L.R. 2004. Herbicide mode of action: Photosynthesis inhibitors. Agronomy 317 - Principles of Weed Science. Available on: http://agron-www.agron.iastate.edu/ Courses/Agron317/Photosynthesis_Inhibitors.htm [Accessed: July 23, 2004]

Lowe S., Browne M., Boudjelas S., De Poorter M. 2000. 100 of the World's Worst Invasive Alien Species. A selection from the Global Invasive Species Database. Available on: www.issg. org/booklet.pdf [Accessed: December 12, 2000]

Luque G.M., Bellard C., Bertelsmeier C., Bonnaud E., Genovesi P., Simberloff D., Courchamp F. 2013. Alien species: Monster fern makes IUCN invader list. Nature 498 (7452): 37.

Murphy T.R. 1999. Turfgrass herbicide mode of action and environmental fate. The University of Georgia. Available on: http://www.commodities.caes.uga.edu/turfgrass/georgiaturf/WeedMngt/weedcontrol/TURFMOA.PDF [Accessed: March, 1999]

Nekonam M.S., Razmjoo J., Kraimmojeni H., Sharifnabi N., Amini H., Bahrami F. 2014. Assessment of some medicinal plants for their allelopathic potential against redroot pigweed (Amaranthus retroflexus). Journal of Plant Protection Research 54 (1): 90-95.

Owen M.D.K. 2002. Acetic acid (vinegar) for weed control revisited. Integrated Crop Management. Available on: http://www. weeds.iastate.edu/weednews/vinegar.htm [Accessed: July 8, 2002]

Parolin P., Rudolph B., Bartel S., Bresch C., Poncet C. 2012. Worldwide invasion pathways of the South American Eichhornia crassipes. Acta Horticulturae 937: 1133-1140. 
Ray P., Kumar S., Pandey S. 2009. Impact evaluation of Neochetina spp. on different growth stages of water hyacinth. Journal of Plant Protection Research 49 (1): 7-14.

Romero-Sierra C., Webb J.C. 1981. Water, alcohols, acids. Preservation of open tissues (US4278715A). Available on: http:// www.google.com/patents/US4278715

[Accessed: July 14, 1981]

Smith-Fiola D., Gill S. 2014. Vinegar: an alternative to glyphosate? University of Maryland Extension. Available on: http://extension.umd.edu/sites/default/files/_docs/ programs/ipmnet/Vinegar-AnAlternative ToGlyphosate-UMD-Smith-Fiola-and-Gill.pdf [Accessed: July, 2014]

Stubbs T.L., Kennedy A.C. 2012. Microbial weed control and microbial herbicides. p. 135-166. In: “Herbicides - Environmental Impact Studies and Management Approaches" (R. Alvarez-Fernandez, ed.), InTech, Rijeka, Croatia, 248 pp.
Summers L.A. 1980. The Bipyridinium Herbicides. Academic Press, New York, USA, 449 pp.

Téllez T.R., López E.M., Granado G.L., Pérez E.A., López R.M., Guzmán J.M.S. 2008. The water hyacinth, Eichhornia crassipes: an invasive plant in the Guadiana River Basin (Spain). Aquatic Invasions 3 (1): 42-53.

Wells R.D.S., Clayton J.S. 2005. Mechanical and chemical control of aquatic weeds: costs and benefits. In: Encyclopedia of Pest Management. DOI: 10.1081/E-EPM-120024643.

Wikipedia, the free encyclopedia 2014. Corrosive substance. Available on: http://en.wikipedia.org/ wiki/Corrosive_substance [Accessed: June, 2014]

Wilson C., Marrone P., Fernandez L., Koivunen M., Campbell B. 2007. Formic acid as an herbicide (US 20070281857 A1). Available on: http://www.google.com/patents/ US20070281857 [Accessed: December 12, 2007] 